Volume 2

Number 2 Teaching Secrecy

January 2021

\title{
Matthew Potolsky's The National Security Sublime: On the Aesthetics of Government Secrecy
}

Nolan Higdon

cSU East Bay, nolanrhigdon@gmail.com

Follow this and additional works at: https://scholarworks.sjsu.edu/secrecyandsociety

Part of the American Studies Commons, and the Critical and Cultural Studies Commons

\section{Recommended Citation}

Higdon, Nolan. 2021. "Matthew Potolsky's The National Security Sublime: On the Aesthetics of Government Secrecy." Secrecy and Society 2(2). https://doi.org/10.31979/ 2377-6188.2021.020211 https://scholarworks.sjsu.edu/secrecyandsociety/vol2/iss2/11

This Book Review is brought to you for free and open access by the School of Information at SJSU ScholarWorks. It has been accepted for inclusion in Secrecy and Society by an authorized administrator of SJSU ScholarWorks. For more information, please contact scholarworks@sjsu.edu.

\section{(c) (1)}

This work is licensed under a Creative Commons Attribution 4.0 License. 


\title{
Matthew Potolsky's The National Security Sublime: On the Aesthetics of Government Secrecy
}

\author{
Abstract \\ Matthew Potolsky's brilliantly woven The National Security Sublime: On the Aesthetics of \\ Government Secrecy offers a powerful and engaging discussion of national security and \\ government secrecy. His findings concerning the influence artists have on citizens' \\ perception of national security is a major contribution to the field. It highlights Americans \\ false sense of awareness regarding government secrecy, that in itself enables government \\ secrecy. Potolsky has made a massive contribution to the study of government secrecy that \\ is sure to spark future research concerning the intersection of national security and \\ aesthetics.
}

\section{Keywords}

aesthetics, civil liberties, cultural studies, film, government secrecy, Indiana Jones, military industrial complex, national security, privacy, security, surveillance, USA PATRIOT Act, XFiles 
Higdon: Book Review: The National Security Sublime

Review, The National Security Sublime: On the Aesthetics of Government Secrecy,

by Matthew Potolsky

Reviewed by Nolan Higdon ${ }^{1}$

The National Security Sublime: On the Aesthetics of Government Secrecy, London: Routledge, 2019. 184 pp. / ISBN: 9780429263958 / https://www.routledge.com/The-National-Security-Sublime-On-theAesthetics-of-Government-Secrecy/Potolsky/p/book/9780367208912

According to Matthew Potolsky, the national security sublime is the "understudied convention for representing the covert activities of the national security state" (3). Through whistleblowers, news reports, governmental documents, and most impressively, media, Potolsky's The National Security Sublime: On the Aesthetics of Government Secrecy, argues that these conventions have broad implications for how Americans perceive government secrecy. Indeed, one would assume that a comprehensive study of the intelligence community would be stymied by secrecy. However, Potolsky brilliantly weaves a narrative based on what is known and unknown to illuminate Americans' shifting perceptions of government secrecy.

1 Nolan Higdon, Ph.D., is a lecturer of history and media studies at California State University, East Bay. Higdon sits on the boards of the Media Freedom Foundation (projectcensored.org); Action Coalition for Media Education (smartmediaeducation.net); and Northwest Alliance For Alternative Media And Education. Higdon is a co-author of United States of Distraction Media Manipulation in Post-Truth America (And What We Can Do About It) with Mickey Huff. He is a co-founding member of the Global Critical Media Literacy Project and co-host of the Along the Line podcast. 
Potolsky concludes that US citizens have gone from fearing to accepting government secrecy.

Potolsky's analysis of government secrecy focuses on the national security state, which he argues has become so large and complex that its shape and contours can only be communicated through aesthetics. Potolsky examines the aesthetics of the national security state from World War II through the so-called War on Terror, paying special attention to how critical events involving the intelligence community have influenced aesthetic conventions. Potolsky, a professor of English at the University of Utah, has an extensive background examining the intersection of the national security state and the Humanities. The book's brevity and style make it well suited for a graduate classroom.

Potolsky's work is well organized, offering extensive analysis with digestible examples from popular culture such as Indiana Jones, JFK, and the $X$-Files, as well as from the news media, including Edward Snowden and the federal government's PRISM program. The first chapter reviews the history of the national security state since World War II, arguing that the public possesses a half knowledge of the intelligence community based on leaks, exposés, reports, and whistleblowers. Potolsky convincingly argues that citizens rely on aesthetic depictions to visualize the intelligence community. In the second chapter, Potolsky employs a historical lens to introduce the concept of aesthetics, and how they have depicted secrecy. 
The third chapter is where Potolsky's thesis begins to take shape through an analysis of the aesthetic depictions of the national security apparatus from World War II to the War on Terror. The fourth chapter analyzes the War on Terror aesthetics of the national security state, especially after 2005, arguing that these depictions reveal the influence of whistleblowers and government leaks on aesthetics. The fifth and final chapter revisits some of the books main findings and Potolsky's main contention that aesthetic depictions of the national security state give Americans a false sense of awareness regarding government secrets.

Potolsky succeeds in making a convincing argument that the national security sublime serves to empower rather than expose government secrecy. Potolsky makes the case that during the War on Terror, aesthetic depictions shifted from exposing deep government conspiracies to describing the mysteries of government secrecy. He writes that the national security sublime abandoned a "desire for totality and coherent explanations and focuses instead on making sense of the imminent physical presence and technological underpinnings of the National Security State" (99). In effect, this gave citizens the illusion that they are face-to-face with the mysteries of the intelligence community when they are in fact beyond their reach.

Much of the strength of Potolsky's book derives from his ability to distill complex concepts to concise paragraphs. For example, in chapter three, Potolsky offers a clear and concise explanation of the complex nature 
of visual and narrative depictions that he references later in the text. He writes that there are three familiar structural elements in the aesthetic depiction of government secrecy:

the privileged view, which describes the special perspective of a knower let in on some secret; the mysterious proliferation, which characterizes the fearful or unbounded nature of the sublime object for that viewer; and the elevated awareness, which defines the effective and intellectual outcome of the encounter with the mystery. The three elements correspond to the three-part movement Immanuel Kant describes in his anatomy of the sublime, by which subjects, (privileged view) encounter an immensity (mysterious proliferation) that threatens to overwhelm them, but rise above their initial perplexity to achieve the affective sense of insight (elevated awareness) associated with sublime experiences. Each translates the moments of judgment into stories judgment into stories, character types, settings, and figures. (60)

Potolsky's writing illustrates a well thought-out and organized study that ensures the reader will not get lost in the dense discussion of aesthetics and government secrecy.

In his brilliantly woven book, Potolsky offers a powerful and engaging discussion of national security and government secrecy. His findings concerning the influence artists have on citizens' perception of national security is a major contribution to the field. It highlights Americans false sense of awareness regarding government secrecy, that in itself enables government secrecy. Potolsky has made a massive contribution to the study of government secrecy that is sure to spark future research concerning the intersection of national security and aesthetics. 